\title{
PENGARUH KOMPENSASI FINANSIAL DAN KOMPENSASI NON- FINANSIAL TERHADAP KINERJA KARYAWAN PADA PT. ANGKASA PURA I (PERSERO) BANDAR UDARA INTERNASIONAL NGURAH RAI BALI
}

\author{
Gusti Agung Wulan Permata Sari \\ Luh Gede Leli Kusuma \\ Ni Putu Eka Mahadewi \\ Email : wulan.permatasari2705@gmail.com \\ PS. S1 Industri Perjalanan Wisata \\ Fakultas Pariwisata UNUD
}

\section{ABSTRACT}

Compensation is everything that constitutes the benefits earned by employees in cash of money or something given directly (financially) or indirect (non-financial) which aimed for reciprocation that given from company on the results of employee performance at work. Compensation can be provided in financial and non-financial. Which including in the financial compensation are salary, bonuses, holiday allowances, superannuation. While that including in non-financial compensation are promotion opportunities, good colleagues, work environment, as well as a special achievement.

The sample of this study is specified using purposive sampling technique using the theory of $J$ Supranto with a total of 150 respondents focused on the permanent employees that worked at PT. Angkasa Pura I (Persero). Analysis of the data was used descriptive qualitative and quantitative including instruments data test, the classic assumption test, multiple regression analysis, correlation and coefficient of determination and hypothesis test partial and simultaneous.

The results of this study that showed the partial test results and simultaneous between the independent variables are financial compensation $\left(X_{1}\right)$ and nonfinancial compensation $\left(X_{2}\right)$ to the dependent variable is the employee performance ( $Y$ ) which has a positive and significant impact to overall the formulating of research hypothesis was resolved. Through the test results of coefficient determination is known that variable financial compensation and non-financial compensation can explain by employee performance at $60 \%$. Multiple Linear Regressions showed that the independent variable has positive coefficient values respectively is 0306 and 0608 with financial compensation as independent variables were the most dominating in affecting the employees' performance at PT. Angkasa Pura I (Persero) Ngurah Rai International Airport in Bali.

Keywords : Financial Compensation, Non-Financial Compensation, Employee Performance.

\section{PENDAHULUAN}

Sektor pariwisata merupakan sektor andalan pemerintah untuk menghasilkan devisa Negara. Dalam dunia pariwisata kita mengenal istilah sarana dan prasana pokok kepariwisataan. Suwena \& Widyatmaja (2010) menjelaskan bahwa Sarana pokok kepariwisataan adalah perusahaan yang hidup dan kehidupannya sangat tergantung dari adanya perjalanan yang dilakukan oleh wisatawan. Sedangkan prasarana kepariwisataan adalah fasilitas yang menunjang proses kegiatan pariwisata dapat berjalan dengan lancar, sehingga dapat memudahkan setiap orang yang terlibat dalam kegiatan berwisata. Industri pariwisata tidak dapat dipisahkan dari sarana dan prasarana pokok kepariwisataan 
karena keduanya saling memiliki keterkaitan satu sama lainnya. Salah satu prasarana pokok kepariwisataan yang menunjang perjalanan calon wisatawan adalah jasa pelayanan bandara. Bandara merupakan tempat pertama kali calon wisatawan akan berkunjung sebelum mereka menuju ke destinasi wisata pada suatu wilayah yang mereka kunjungi.

PT. Angkasa Pura I (Persero) merupakan perusahaan yang bergerak dibidang jasa pelayanan bandara. Sebagai perusahaan yang melayani wisatawan melalui jasa pelayanan bandara tentunya PT. Angkasa Pura I (Persero) memiliki cara dan kiat-kiat untuk memberikan kepuasan kepada wisatawan. Saat ini PT. Angkasa Pura I (Persero) dihadapkan pada permasalahan penurunan jumlah karyawan. Pada data yang ditemukan bahwa pada tahun 2012 jumlah karyawan PT Angkasa Pura I (Persero) sebesar 679 orang dan hingga saat ini pada tahun 2016 jumlah karyawan sebesar 580 yang menunjukkan bahwa terdapat penurunan jumlah karyawan. Menurut Bapak Moh. Setiadi Darmawan selaku Human Capital Section Head menyatakan bahwa penurunan jumlah karyawan disebabkan oleh banyaknya karyawan senior yang pensiun. Banyaknya karyawan pensiun disebabkan oleh faktor usia yang mengharuskan karyawan untuk berhenti bekerja pada suatu perusahaan.

Penurunan kinerja dapat berpengaruh terhadap penurunan jumlah kompensasi yang diberikan perusahaan kepada karyawan, karena penurunan kinerja dapat diukur dari tingkat kehadiran, jumlah pekerjaan, ketepatan waktu menyelesaikan pekerjaan, kemampuan kerjasama, serta kualitas pekerjaan seorang karyawan. Yang berarti bahwa semakin sedikit karyawan dapat menyelesaikan pekerjaan maka semakin sedikit kompensasi yang diterima oleh karyawan. Hubungan kerja yang saling menguntungkan antara perusahaan dengan karyawan sangat diperlukan dalam rangka mendorong semangat kerja karyawan. Karyawan memberikan kinerja yang baik untuk kemajuan perusahaan, sedangkan perusahaan memberikan kompensasi yang sesuai atas kinerja yang telah diberikan karyawan terhadap perusahaan. Gabriella Wibowo dan Roy Setiawan (2014) dalam penelitian yang mereka lakukan juga berpendapat bahwa pemberian kompensasi yang baik sangat berpengaruh penting terhadap kinerja karyawan. Semakin perusahaan memperhatikan sistem pemberian kompensasi maka kinerja dari karyawan pun akan meningkat. Berdasarkan latar belakang sebelumnya, maka dapat dijelaskan tujuan dari penelitian ini adalah untuk mengetahui bagaimana pengaruh kompensasi finansial dan kompensasi non-finansial terhadap kinerja karyawan baik secara parsial maupun secara simultan.

\section{METODE PENELITIAN}

Penelitian ini dilakukan di PT Angkasa Pura I (Persero) Bandar Udara Internasional Ngurah Rai Bali. Penelitian ini terfokus kepada karyawan tetap (organik). Dalam penelitian ini terdiri dari atas variabel bebas yaitu kompensasi finansial $\left(\mathrm{X}_{1}\right)$ dan kompensasi non finansial $\left(\mathrm{X}_{2}\right)$ dan variabel terikat yaitu kinerja karyawan $(\mathrm{Y})$.

Jenis data yang digunakan dalam penelitian ini terdiri dari data kualitatif dan data kuantitatif. Penelitian ini menggunakan data primer diantaranya data hasil penyebaran kuesioner dan wawancara. Teknik penentuan sampel yang digunakan adalah purposive sampling. Jumlah sampel mengacu pada model penentuan sampel yang dikemukakan oleh J. Supranto (dalam Kiskenda, 2015). Dalam penelitian ini jumlah indikator yang dipergunakan sebanyak 30, maka jumlah responden yang akan dijadikan sampel adalah 150 orang yang didapat dengan mengalikan jumlah indikator (30) dengan (5).

\section{HASIL DAN PEMBAHASAN Uji Instrument Data}

Instrumen data diuji dengan menggunakan uji validitas dan reliabilitas. Berdasarkan uji validitas dalam penelitian ini, dinyatakan nilai $\mathrm{r}_{\text {hitung }}$ untuk seluruh indikator penelitian memiliki nilai yang positif dan lebih besar dari nilai $r_{\text {tabel }}$ (0.1603). Maka dapat diartikan keseluruhan indikator dalam penelitian ini adalah valid.

Untuk mengukur reliabel atau tidaknya sebuah variabel maka dalam pengujian menggunakan teori Alpha Cronbranch $(\alpha)$ yang memiliki nilai koefisien Alpha lebih besar dari 0.6 (Sugiyono, 2006). Diketahui bahwa keseluruhan variabel memiliki nilai koefisien Alpha lebih besar dari 0,6. Berawal dari hal 
tersebut maka variabel dalam penelitian dinyatakan reliable untuk penelitian.

\section{Uji Asumsi Klasik}

Asumsi klasik diuji dengan menggunakan uji normalitas, uji multikulinearitas, dan uji heteroskedastisitas. Berdasarkan uji normalitas dengan metode One Sample KolmogorovSmirnov Test menunjukkan bahwa Asymp. Sig 2-tailed sebesar 0.125 yang berarti bahwa nilai signifikan yang dihasilkan dari perhitungan ini lebih besar dari 0.05 yang berarti bahwa data yang diteliti berdistribusi normal dan memenuhi asumsi uji normalitas.

Pengujian Multikolinearitas dilihat dari nilai tolerance dan Varian Inflation Factor (VIF) yang dihasilkan setelah pengujian dilakukan Berdasarkan hasil yang didapat dalam penelitian ini bahwa nilai tolerance $(0.397)$ dan nilai VIF (2.518) yang berarti tidak terjadi multikolinearitas antar variabel bebas dalam model regresi dalam penelitian ini.

Uji Heteroskedastisitas menggunakan uji glejser, hasilnya berupa angka yang menandakan tinggi rendahnya heteroskedastisitas yang terjadi dalam penelitian. Pada penelitian ini taraf signifikansi yang ditetapkan sebesar 0.05 , hasil yang didapat memiliki nilai masing-masing sebesar 0,081 dan 0,690. Yang artinya tidak terjadi gejala heteroskedastisitas dalam penelitian ini.

\section{Analisis Regresi Linier Berganda}

Berdasarkan hasil yang di dapat maka dapat dilihat nilai koefisien determinasi memiliki adjusted R Square sebesar 0.600 menunjukkan $60 \%$ variabel-variabel kinerja karyawan (Y) yang dapat dijelaskan oleh variabel-variabel bebas dalam penelitian ini yaitu Kompensasi Finansial (X1) dan Kompensasi Non Finansial (X2). Sedangkan sisanya yaitu sebesar $40 \%$ dijelaskan oleh variabel-variabel lain yang tidak termasuk dalam penelitian ini.

\section{Uji Hipotesis}

\section{Uji Signifikansi Parsial (t)}

Dalam pengujian uji t terdapat dua dasar pengambilan keputusan dimana dapat dilihat melalui nilai signifikansi dan nilai $t_{\text {hitung }}$ dan $t_{\text {tabel }}$. Berdasarkan hasil uji yang di dapat, penelitian ini memiliki taraf signifikansi 0.000 dan tidak melebihi 0.05 . Dimana masing-masing variabel bebas memiliki nilai $t_{\text {hitung }}$ sebesar 5.462 dan 4.575 , yang berarti bahwa variabel bebas yaitu kompensasi finansial $\left(\mathrm{X}_{1}\right)$ dan kompensasi non finansial $\left(\mathrm{X}_{2}\right)$ berpengaruh terhadap variabel terikat yaitu kinerja karyawan (y).

\section{Uji Signifikansi Simultan (F)}

Dalam uji $F$ metode yang digunakan adalah ANOVA atau $\mathrm{F}$ test. Yang dimana dilihat melalui taraf signifikansi dan juga membandingkan antara $f_{\text {hitung }}$ dan $f_{\text {tabel }}$. Berdasarkan hasil tersebut maka diperoleh $\mathrm{F}_{\text {hitung }}$ sebesar 112.778 dengan taraf signifikansi 0.000 . Yang berarti nilai signifikansi kurang dari 0.05 yang berarti Ho ditolak dan Ha diterima, dimana dalam penelitian didapatkan hasil bahwa $f_{\text {hitung }}$ sebesar 112.778 lebih besar dibandingkan dengan $\mathrm{f}_{\text {tabel }}$ sebesar 3.06 maka $\mathrm{H}_{3}$ yaitu kompensasi finansial dan kompensasi non finansial berpengaruh positif dan signifikan terhadap kinerja karyawan secara simultan diterima.

Berdasarkan hasil analisis regresi berganda mendapatkan model regresi $\mathrm{Y}=16.041$ $+0.306 \mathrm{X}_{1}+0.608 \mathrm{X}_{2}+\mathrm{e}$, yang dimana nilai koefisien regresi dalam penelitian ini bernilai positif yang artinya semakin tinggi nilai varibel $\mathrm{X}$ maka secara otomatis variabel $\mathrm{Y}$ juga akan mengalami peningkatan dan begitu juga sebaliknya. Berdasarkan pada pengujian hipotesis yang dilakukan maka akan dikemukakan pengaruh masing-masing variabel bebas terhadap variabel terikat sebagai berikut:

\section{Pengaruh Kompensasi Finansial terhadap Kinerja Karyawan}

Hipotesis pertama menunjukkan bahwa kompensasi finansial berpengaruh positif dan signifikan terhadap kinerja karyawan. Berdasarkan nilai $t_{\text {hitung }}$ sebesar 5.462 yang dihasilkan pada variabel kompensasi finansial lebih besar dari nilai $t_{\text {tabel }}$ sebesar 1.976. Dengan demikian hasil pengujian hipotesis menunjukkan arah positif tang berarti bahwa nilai koefisien 0.306 maka $\mathrm{H}_{\mathrm{o}}$ ditolak $\mathrm{H}_{\mathrm{a}}$ diterima dengan signifikansi 0.000 yang lebih kecil dari taraf signifikansi yang ditentukan sebesar 0.05 maka dengan hal tersebut variabel kompensasi 
finansial dinyatakan mempengaruhi variabel kinerja karyawan.

Kompensasi Finansial diberikan sesuai dengan kesepakatan yang terjadi antar perusahaan dengan karyawan. Kompensasi yang diberikan secara baik oleh perusahaan kepada karyawan akan meningkat motivasi karyawan dalam bekerja sehingga kinerja mereka pun akan baik. Karena kompensasi dipandang merupakan suatu sistem imbalan yang dapat memotivasi karyawan dalam bekerja, kompensasi merupakan bentuk keuntungan yang nyata yang diterima oleh karyawan sebagai bagian dari hubungan kepegawaian Bernardin \& Russell (1998). Kompensasi finansial merupakan bayaran nyata yang diterima oleh karyawan selama mereka bekerja pada suatu perusahaan.

Berdasarkan hasil dari pengukuran persepsi karyawan terhadap variabel kompensasi finansial dengan menggunakan 150 responden maka diketahui bahwa karyawan memberikan nilai tertinggi pada indikator tunjangan hari raya yang mana dapat diartikan bahwa tunjangan yang diberikan oleh perusahaan mampu membantu perekonomian karyawan selain menerima gaji pokok. Pada sisi lainnya karyawan memberikan nilai terendah pada indikator kendaraan namun masih berada dalam kategori setuju. Hasil ini dapat dinyatakan bahwa tidak seluruh karyawan merasakan fasilitas kendaraan yang diberikan perusahaan. Menurut wawancara awal yang dilakukan dengan kepala bagian kepegawaian bahwa fasilitas kendaraan hanya diterima oleh karyawan dengan level manager.

Dapat disimpulkan bahwa semakin terpenuhinya kompensasi finansial yang diberikan perusahaan kepada karyawan maka secara otomatis hal tersebut akan meningkatkan kinerja karyawan begitu juga sebaliknya. Karena semakin karyawan merasa sejahtera bekerja dalam suatu perusahaan maka loyalitas mereka bekerja dalam perusahaan akan semakin tinggi maka kinerja mereka juga akan semakin baik. Hasil penelitian ini sesuai dengan beberapa hasil penelitian yang telah dilakukan oleh Ekshu Hamdan dan Roy Setiawan (2014).

\section{Pengaruh Kompensasi Non Finansial terhadap Kinerja Karyawan}

Hipotesis kedua menunjukkan bahwa kompensasi non finansial berpengaruh positif dan signifikan terhadap kinerja karyawan. Berdasarkan nilai $t_{\text {hitung }}$ sebesar 4.575 yang dihasilkan pada variabel kompensasi non finansial lebih besar dari nilai $t_{\text {tabel }}$ sebesar 1.976. Dengan demikian hasil pengujian hipotesis menunjukkan arah yang positif bahwa nilai koefisien 0.608 maka $\mathrm{H}_{0}$ ditolak $\mathrm{H}_{\mathrm{a}}$ diterima dengan signifikansi 0.000 yang lebih kecil dari taraf signifikansi yang ditentukan sebesar 0.05 maka dengan hal tersebut variabel kompensasi non finansial dinyatakan mempengaruhi variabel kinerja karyawan.

Kompensasi non-finansial merupakan imbalan dalam bentuk kepuasan seorang karyawan yang diperoleh dari pekerjaan itu sendiri, atau dari lingkungan baik secara fisik atau psikologis dimana karyawan tersebut bekerja, Syaifullah (2005:9). Dampak dari kompensasi non-finansial dapat dirasakan secara langsung maupun tidak langsung karena memerlukan tahapan-tahapan agar kompensasi finansial tersebut terjadi. Kompensasi nonfinansial merupakan salah satu bagian dari kompensasi yang juga penting untuk diteliti karena berhubungan langsung dengan keadaan para karyawan dalam bekerja. Keadaan yang dimaksud adalah kepuasan mereka akan rekan kerja, lingkungan kerja, promosi, dan juga penghargaan yang diterima oleh karyawan jika mereka berprestasi.

Berdasarkan hasil dari pengukuran persepsi karyawan terhadap variabel kompensasi non-finansial dengan menggunakan 150 responden maka diketahui bahwa karyawan memberikan nilai tertinggi pada indikator rekan kerja yang dapat diartikan bahwa rekan kerja dalam perusahaan mampu memberikan rasa nyaman karyawan dalam bekerja. Pada sisi lainnya karyawan memberikan nilai terendah pada indikator peluang promosi namun masih berada dalam kategori setuju. Hasil ini dapat dinyatakan bahwa tidak seluruh karyawan menerima promosi dari perusahaan mereka selama berkerja. Menurut wawancara awal yang dilakukan dengan kepala bagian kepegawaian bahwa peluang promosi hanya diberikan kepada karyawan yang berprestasi selama bekerja. Hasil 
penelitian ini juga didukung oleh penelitian sebelumnya yang dilakukan oleh Oburu Lewis Nyaribo \& Atambo Wallace Nyakundi PhD (2016) menyatakan bahwa kompensasi nonfinansial memiliki pengaruh yang kuat dan positif terhadap kinerja karyawan.

Dapat disimpulkan bahwa jika kompensasi non-finansial yang diberikan perusahaan kepada karyawan terpenuhi maka kinerja karyawan pun akan semakin baik. Seperti yang sudah dijelaskan sebelumnya kompensasi non-finansial dapat dirasakan karyawan baik secara langsung dan tidak langsung sesuai dengan kinerja karyawan itu sendiri. Jika karyawan memiliki kinerja yang baik maka karyawan akan merasa puas terhadap kompensasi non-finansial yang disediakan oleh perusahaan. Sebaliknya jika karyawan tidak memiliki kinerja yang baik maka kompensasi non-finansial yang diberikan perusahaan tidak akan termanfaatkan secara optimal.

\section{Pengaruh Kompensasi Finansial dan Non Finansial terhadap Kinerja Karyawan}

Hipotesis ketiga menunjukkan bahwa kompensasi finansial dan non finansial berpengaruh positif dan signifikan terhadap kinerja karyawan. Hasil pengujian hipotesis menunjukkan arah yang positif bahwa nilai $f_{\text {hitung }}$ sebesar 112.778 lebih besar daripada $f_{\text {tabel }}$ sebesar 3.06 dengan taraf signifikansi 0.000 yang lebih kecil dari taraf signifikansi yang ditentukan sebesar 0.05 yang berarti $\mathrm{H}_{\mathrm{o}}$ ditolak dan $\mathrm{H}_{\mathrm{a}}$ diterima.

Pemberian kompensasi baik finansial dan non-finansial dapat membantu dan memotivasi karyawan dalam bekerja. Tujuan pemberian kompensasi adalah untuk meningkatkan kinerja dari karyawan selama bekerja. Kompensasi yang baik adalah kompensasi yang sesuai dengan kebutuhan seorang karyawan. Pemberian kompensasi merupakan hubungan timbal balik perusahaan dengan karyawan. Karyawan memberikan kinerja yang baik kepada perusahaan untuk mencapai tujuan perusahaan, perusahaan memberikan imbalan kepada karyawan atas kerja keras yang mereka berikan kepada perusahaan berupa kompensasi. Hasil penelitian ini juga sesuai dengan penelitian yang dilakukan oleh Nor Lenni (2014) dan Ekshu Hamdan dan Roy Setiawan (2014) yang menyatakan bahwa kompensasi finansial dan non finansial berpengaruh signifikan terhadap kinerja karyawan.

Dapat disimpulkan bahwa semakin

terpenuhinya kompensasi finansial dan kompensasi non-finansial yang diberikan perusahaan kepada karyawan maka akan memotivasi karyawan bekerja dan memberikan kinerja yang semakin baik. Kompensasi finansial dan kompensasi non-finansial memberikan pengaruh positif dan signifikan terhadap kinerja karyawan sehingga kedua variabel ini dapat dijadikan tolak ukur dan harus diperhatikan untuk menjaga kinerja dari karyawan agar tetap baik.

\section{SIMPULAN DAN SARAN Simpulan}

Model regresi yang dihasilkan pada penelitian ini terbebas dari gejala uji asumsi klasik dan memenuhi syarat uji normalitas, uji multikolinearitas dan uji heteroskedastisitas. Nilai korelasi antara variabel bebas dan terikat berada pada kategori sedang namun masih dalam kategori positif dan memiliki nilai koefisien determinasi sebesar $60 \%$ yang artinya kompensasi finansial dan kompensasi nonfinansial mampu menjelaskan kinerja karyawan.

Hasil uji parsial menyatakan variabel bebas berpengaruh positif dan signifikan terhadap kinerja karyawan diketahui nilai $t_{\text {hitung }}$ lebih besar dari $t_{\text {tabel }}$ dan nilai signifikansi $<0,05$. Sehingga hipotesis dalam penelitian ini diterima. Hasil uji simultan menyatakan variabel kompensasi finansial dan kompensasi nonfinansial secara bersama mempengaruhi kinerja karyawan dengan perhitungan nilai $F_{\text {hitung }}>F_{\text {tabel }}$.

Dapat disimpulkan bahwa kinerja karyawan akan semakin membaik jika pemberian kompensasi yang diberikan terpenuhi. Jika sistem pemberian kompensasi oleh perusahaan berjalan dengan maik maka kinerja karyawan pun akan semakin meningkat. Kompensasi merupakan motivasi karyawan dalam bekerja.

\section{Saran}

Pihak PT Angkasa Pura I (Persero) sebaiknya lebih memerhatikan fasilitas kendaraan yang diberikan kepada karyawan, karena nilai indikator kendaraan terendah dari 
indikator lainnya namun masih dalam kategori setuju. Sebaiknya fasilitas kendaraan yang disediakan perusahaan diberikan juga kepada karyawan yang tidak memiliki kendaraan bukan hanya pada level manager/pejabat. Sebaiknya pemberian tunjangan transportasi ditingkatkan untuk meringankan beban karyawan yang tidak memiliki kendaraan. Saran tersebut dilihat berdasarkan penilaian karyawan dalam menjawab kuesioner.

\section{DAFTAR PUSTAKA}

Bernadin, John H, Joyce H Russel. 1998. Human Resources Management: An Experiental Approach. Mc Graw-Hill.

Ekshu Hamdan dan Roy Setiawan. 2014. Pengaruh Kompensasi Finansial Dan Non Finansial Terhadap Kinerja Karyawan PT. Samudera Buana Persada. Jurnal. Program Manajemen Bisnis, Program Studi Manajemen, Universitas Kristen Petra

Gabriella Wibowo, Roy Setiawan. 2014. Pengaruh Kompensasi Finansial dan Non Finansial terhadap Kinerja Karyawan di CV. Sejahtera Mobil Surabaya. Jurnal. Universitas Kristen Petra. AGORA. 2 (1).

Nor Lenni. 2014. Pengaruh Kompensasi Finansial dan Non-Finansial terhadap
Kinerja Karyawan PT. Pertamina EP Bunyu Field Kabupaten Bulungan. eJournal Ilmu Administrasi Bisnis, 2014, 2 (4) : 513 - 526 ISSN 2355-5408.

Oburu Lewis Nyaribo \& Atambo Wallace Nyakundi PhD. 2016. The Effect of NonFinancial Compensation on Employee Performance of Micro Finance Institution: A case of Wakenya Pamoja Sacco Kissi County Kenya. Imperial Journal of Interdisciplinary Research (IJIR) Vol-2. Issue-6. ISSN: 2454-1362

Putra, Kiskenda Erwanda. 2015. Peran Pengalaman sebagai Pomoderasi pada Pengaruh Pengetahuam dan Sikap Wisatawan Mancanegara terhadap Keputusan Pembelian Produk Wellness Tourism di Kawasan Wisata Ubud. Kabupaten Gianyar. Skripsi. Fakultas Pariwisata Universitas Udayana.

Suwena, Ketut \& Gusti Ngurah Widyatmaja. 2010. Pengetahuan Dasar Ilmu Pariwisata. Denpasar: Udayana Press.

Syaifullah. 2005. Pengertian Kompensasi dan Jenis Kompensasi. http://pengertiankompensasi.html diakses 28 September 2016. 